\title{
OPTIMASI PEMANFAATAN PESTISIDA NABATI SEBAGAI SISTEM PERTANIAN BERKELANJUTAN DALAM MENDUKUNG KETAHANAN PANGAN GORONTALO
}

\author{
Merita Ayu Indrianti ${ }^{1}$ \\ email: $\underline{\text { ayusutarto@umgo.ac.id }}$ \\ ${ }^{1}$ Tenaga Pengajar Program Studi Agribisnis, Fakultas Ilmu-Ilmu Pertanian \\ Universitas Muhammadiyah Gorontalo \\ Jl. Prof. H. Mansoer Pateda, Gorontalo, Indonesia
}

\begin{abstract}
The purpose of this study is to optimize the use of environmentally friendly vegetable pesticides as a sustainable agricultural system. This research was conducted in April - August 2019 in the Green House and Tarpaulin Pond Field Laboratory of the Faculty of Agricultural Sciences, Muhammadiyah University, Gorontalo. The design used was a Randomized Block Design (RBD) with four treatment factors, namely giving water hyacinth filtrate, giving filtrate variations with other vegetable materials (1:1 ratio) and finally the control stage. Each vegetable ingredient filtrate is then used in spraying all parts of the plant in the morning. The analysis in this research uses oneway analyst which continued with Duncan's test with a significance level of 5\%. The results showed that vegetable pesticides from water hyacinth filtrate and papaya leaf filtrate can be used to reduce the intensity of the attack (\%) of the curly yellow virus vector, whitefly (Bemisia tabaci) attacking the F1 Dewata chili plant, the use of a mixture of water hyacinth filtrate and papaya leaf filtrate with a ratio of 1: 1 is effective in reducing the intensity of white lice infestation (Bemisia tabaci) on the red chilli F1 F1 variety by $82.34 \%$ but the fruit production is unsatisfactory and the use of water hyacinth filtrate can increase the production of red chillies F1 Dewata variety by suppressing the intensity of whitefly infestation (Bemisia tabaci) by $65.55 \%$.
\end{abstract}

Keywords: vegetable pesticides, water hyacinth, food security and gorontalo

\begin{abstract}
Abstrak. Tujuan penelitian ini adalah untuk mengoptimasi pemanfaatan pestisida nabati ramah lingkungan sebagai sistem pertanian yang berkelanjutan. Penelitian ini dilakukan pada bulan April - Agustus 2019 di Green House dan Kolam Terpal Laboratorium Lapangan Fakultas Ilmu-Ilmu Pertanian Universitas Muhammadiyah Gorontalo. Rancangan yang digunakan adalah Rancangan Acak Kelompok (RAK) dengan empat faktor perlakuan yaitu pemberian filtrate eceng gondok, pemberian filtrate variasi dengan bahan nabati lainnya (perbandingan 1:1) dan terakhir tahap kontrol. Masing-masing filtrate bahan nabati selanjutnya digunakan pada penyemprotan pada seluruh bagian tanaman di waktu pagi hari. Analisis dalam penelitian menggunakan analis satu arah yang dilanjutkan dengan uji Duncan dengan taraf signifikan 5\%. Hasil penelitian menunjukkan bahwa pestisida nabati dari filtrat enceng gondok dan filtrat daun pepaya dapat digunakan untuk menekan intensitas serangan (\%) vektor virus kuning keriting, kutu kebul (Bemisia tabaci) yang menyerang tanaman cabai varietas Dewata F1, penggunaan filtrat campuran berupa filtrat enceng gondok dan filtrat daun pepaya dengan perbandingan 1:1 efektif dalam mengurangi intensitas serangan kutu kebul (Bemisia tabaci) pada tanaman cabai merah varietas Dewata F1 sebesar 82,34\% namun produksi buahnya kurang memuaskan dan penggunaan filtrat enceng gondok dapat menaikkan produksi buah cabai merah vareitas Dewata F1 dengan menekan intensitas serangan kutu kebul (Bemisia tabaci) sebesar 65,55\%.
\end{abstract}

Kata kunci: pestisida nabati, eceng gondok, ketahanan pangan dan gorontalo 


\section{PENDAHULUAN}

Indonesia merupakan salah satu negara yang memiliki sumber daya lahan pertanian terbesar di Asia tenggara maupun di dunia. Negara kepulauan yang memanjang dari Sabang sampai Merauke ini memiliki daratan yang luasnya diperkirakan mencapai hingga 1.913.578,68 $\mathrm{km}^{2}$ (BPS, 2017) dengan memiliki keanekaragaman jenis tanah, bahan induk, bentuk wilayah, ketinggian tempat dan iklim, berupa lahan kering, lahan rawa dan non-rawa. Hal ini merupakan sebuah potensi besar bagi bangsa Indonesia dalam memproduksi berbagai komoditas pertanian, perkebunan hingga perikanan secara berkelanjutan (Hidayat, 2009). Pemanfaatan lahan secara optimal dan berkelanjutan akan memberi dampak yang signifikan pada peningkatan perekonomian negara dan juga masyarakat. Sehingga atas dasar ini maka Pemerintah Indonesia melalui Menteri Agraria dan Tata Ruang (Kementerian Agraria Dan Tata Ruang Republik Indonesia, 2016) mengeluarkan peraturan tentang penetapan lahan pertanian berkelanjutan sebagai dukungan untuk mencapai ketahanan pangan nasional.

Selain menjadi komitmen Pemerintah Indonesia pada ketahanan pangan nasional, hal ini juga menjadi strategi untuk mengantisipasi menurunnya kualitas dan kuantitas produksi pertanian sebagai implementasi dalam mencapai tujuan pembangunan berkelanjutan ke-2, yaitu mengakhiri kelaparan, atau pada tingkat global dinyatakan sebagai 2nd Sustainable Development Goals (2nd SDGs, Zero Hunger) (Kementerian
Agraria Dan Tata Ruang Republik Indonesia, 2016). Komitmen dan tujuan pemerintah ini tentu saja juga harus mendapat dukungan penuh dari pihak akademisi maupun masyarakat yang menjadi penggerak ekonomi di bidang pangan, yaitu pertanian dan perikanan. Seperti diantaranya adalah harus lebih banyak upaya dan inovasi untuk meningkatkan produksi pertanian secara berkelanjutan, meningkatkan rantai pasokan global, mengurangi kerugian produksi akibat cuaca dan bencana, serta memastikan bahwa semua yang menderita kelaparan dan kekurangan gizi memiliki jaminan atas kualitas hasil pertanian. Hal ini dapat dilakukan dengan menerapkan sistem pangan produktif yaitu dengan menggabungkan beberapa elemen yang berasal dari pengetahuan petani tradisional yang diperkaya oleh pengetahuan ilmiah terbaru, yaitu diantaranya adalah melalui pengelolaan tanah, air, nutrisi dan hama yang sehat dan berkelanjutan, penggunaan pupuk organik serta pemanfaatan pestisida nabati yang lebih luas (United Nation, 2012). Sehingga atas dasar hal tersebut, penerapan sistem pangan produktif sebagai sebuah sistem pertanian dan perikanan berkelanjutan dalam mendukung ketahanan pangan nasional harus segera dioptimasi pada beberapa wilayah di Indonesia termasuk di daerah Gorontalo. Salah satu sistem pangan produktif yang rencana dilakukan di daerah ini adalah dengan mengoptimasi pemanfaatan pestisida nabati ramah lingkungan untuk dapat diterapkan oleh masyarakat Desa Pentadio Timur di Kecamatan Telaga Biru Kabuptaen Gorontalo 
yang juga merupakan Desa Mitra Universitas Muhammadiyah Gorontalo. Sehingga diharapkan dengan keberhasilan tujuan penelitian ini, tidak saja akan mendukung program ketahanan pangan dan tujuan pembangunan berkelanjutan Pemerintah Indonesia, tetapi juga bermanfaat menjadi sebuah percontohan dalam system pertanian dan perikanan berkelanjutan yang dapat diterapkan di daerah lain.

\section{BAHAN DAN METODE}

Penelitian dilaksanakan setelah sejak bulan April hingga dengan bulan Agustus 2019 meliputi tahap pengusulan, persiapan, survei pendahuluan, pengumpulan bahan percobaan, pengolahan data, penyusunan laporan dan penerbitan artikel pada jurnal ilmiah tidak terakreditasi sebagai luaran yang diharapkan. Pembuatan pestisida nabati akan dipusatkan di Green House Laboratorium Lapangan Fakultas Ilmu-Ilmu Pertanian Universitas Muhammadiyah Gorontalo (UMGo) dan tahap uji coba produk hasil penelitian akan diuji perlakuan pada bibit ikan Laboratorium Kolam Terpal serta pada tanaman cabai di laha pertanian warga Desa Pentadio Timur yang merupalan Desa Binaan UMGo.

\section{Tahap Pembuatan Pestisida}

Tahap ini dilakukan pembuatan pestisida nabati dengan bahan utama eceng gondok dengan percobaan variasi.

1. Eceng gondok (1000 gram) dengan penambahan bakteri fermentasi bahan organik tanah (EM-4, 10 gram) akan dihaluskan menggunakan blender. Penggunaan EM-4 untuk membantu proses fermentasi eceng gondok agar berfungsi sebagai perekat hama ketika digunakan sabagai pestisida

2. Hasil blender direndam dalam $1000 \mathrm{ml}$ air dan didiamkan selama 20 jam

3. Hasil blender disaring untuk diambil airnya/larutannya yang akan dimanfaatkan menjadi pestisida nabati

4. Langkah-langkah percobaan dengan variasi bahan gabungan eceng gondok dengan bahan lainnya bisa juga diuji cobakan dengan tetap mengikuti langkah yang sama seperti sebelumnya

5. Pestisida nabati siap untuk digunakan atau di uji coba pada lahan pertanian

\section{Tahap Uji Coba Pestisida}

Sebelum melakukan tahap ini, terlebih dahulu menyiapkan lahan pertanian untuk dibajak dan dilakukan pengapuran. Pengapuran memanfaatkan bahan dolomit yang berfungsi menetralkan $\mathrm{pH}$ tanah, pemberian pupuk kandangan dan pupuk dasar ZA, Urea dan Phonska. Selanjutnya adalah pembuatan bedengan, pemasangan mulsa plastik, pembuatan lubang tanam dan pemasangan pipa irigasi untuk penanaman benih cabai yang sebelumnya direndam dengan fungisida dan disemai terlebih dahulu dalam media selama 5-7 hari. Setelah umur tanaman masuk pada hari ke-8, tanaman dipindahkan ke lahan pertanian dari media persemaian untuk diuji coba dengan perlakuan berbeda filtrat. Tanaman diamati setiap tiga hari sekali hingga panen untuk melihat tingkat kerusakan daun.

Aplikasi perlakuan dengan menyemprotkan masing-masing filtrat bahan nabati pada waktu 
pagi hari keseluruh bagian tanaman. Penelitian yang digunakan adalah eksperimen menggunakan Rancangan Acak Kelompok (RAK) dengan empat faktor perlakuan dan enam kali pengulangan untuk masing-masing faktor perlakuan. Penelitian ini dianalisis menggunakan anava satu arah dan dilanjutkan dengan uji Duncan dengan taraf signifikansi 5\% menggunakan perangkat lunak SPSS versi 17.0 for Windows. Faktor perlakuan yang dilakukan antara lain adalah:
A. Pemberian Filtrat Eceng Gondok
B. Pemberian Filtrat Bahan Lainnya
C. Pemberian Filtrat Eceng Gondok dan Bahan Lain (1:1)
D. Kontrol

\section{HASIL DAN PEMBAHASAN}

Berdasarkan penghitungan SPSS dengan anava satu arah, diperoleh nilai $\mathrm{F}$ hitung sebesar 62,35 dengan signifikansi 0,010.
Nilai $\mathrm{F}$ hitung lebih besar dari nilai $F$ tabel yaitu 3,29 . Hal ini berarti signifikan, dimana ada perbedaan pemberian filtrat enceng gondok, filtrat daun pepaya dan filtrat campuran terhadap intensitas serangan (\%) kutu kebul (Bemisia tabaci) pada tanaman cabai varietas Dewata F1.

Berdasarkan hasil analisis dan tabel diatas dapat diketahui bahwa pada perlakuan kontrol, intensitas serangan kutu kebul pada tanaman cabai terlihat paling tinggi ditandai dengan prosentase intensitas serangan hingga mencapai 45,22\%. Kerusakan yang ditimbulkan akibat serangan kutu kebul ini yaitu daun yang berbercak kecoklatan, kemudian sekitaran daun mengeriting. Hal tersebut terlihat berbeda dengan tiga perlakuan lainnya yang masing-masing diberi filtrat enceng gondok, filtrat daun pepaya, dan filtrat campuran dari keduanya.

Tabel 1. Intensitas Serangan (\%) Hama pada Tanaman Cabai

\begin{tabular}{lcc}
\hline \multicolumn{1}{c}{ Perlakuan } & $\begin{array}{c}\text { Rata-Rat intensitas } \\
\text { Serangan }(\%)\end{array}$ & $\begin{array}{c}\text { Rata-Rata Produksi } \\
\text { Buah (Biji) }\end{array}$ \\
\hline $\begin{array}{l}\text { Filtrat Eceng } \\
\text { Gondok }\end{array}$ & 40,45 & 21 \\
\hline $\begin{array}{l}\text { Filtrat Daun } \\
\text { Pepaya }\end{array}$ & 47,87 & 16 \\
\hline Filtrat Campuran & 13,58 & 14 \\
\hline Kontrol & 45,22 & 10 \\
\hline
\end{tabular}

Pada perlakuan pemberian filtrat enceng gondok dan filtrat daun pepaya memberikan pengaruh yang hampir sama, hanya saja pemberian filtrat enceng gondok lebih efektif menekan prosentase intensitas serangan kutu kebul hingga sebesar $\quad 40,45 \%$ dibanding pemberian filtrate daun pepaya dimana prosentase intensitas serangannya mencapai 47,87\%. Pengamatan yang menunjukkan hasil paling bagus adalah perlakuan pemberian filtrat campuran denga $n$ presentase intensitas serangan yang dapat ditekan hingga hanya tinggal $13,58 \%$. Pada perlakuan ini terjadi penambahan dua substansi yang masing-masing memiliki kandungan senyawa 
aktif yang berperan sebagai anti serangga dan juga anti bakteri dan virus. Filtrat daun enceng gondok mengandung saponin, dan flavonoid.

$$
\text { Saponin mempunyai }
$$

kegunaan sebagai racun dan antimikroba (jamur, bakteri, virus), bersifat antioksidan dan antikarsinogenik. Saponin

merupakan golongan senyawa glikosida yang mempunyai struktur steroid. Glikosidasaponin bisa berupa saponin steroid maupun saponin triterpenoid. Saponin bersifat menghancurkan butir darah merah lewat reaksi haemolisis. Flavonoid berperan langsung sebagai antibiotik dengan mengganggu fungsi dari mikroorganisme. Mekanisme kerja flavonoid dengan merusak permeabilitas barrier mikroorganisme, sehingga terjadi kerusakan membran sel. Flavonoid termasuk dalam senyawa fenolik, jika senyawa fenolik ini terdapat dalam jumlah yang besar mampu menginaktifkan enzim-enzim esensial di dalam tubuh mikroorganisme.

Sedangkan alkaloid adalah bahan organik yang mengandung nitrogen sebagai bahan dari sistem heterosiklik yang berperan sebagai zat racun yang melindungi tumbuhan dari gangguan serangga. Mekanisme alkaloid dengan cara mendenaturasi protein dan merusak membran sel. Gabungan dari kedua filtrat tersebut menyebabkan perlakuan filtrat campuran menjadi paling efektif dalam menghambat serangan kutu kebul (Bemisia tabaci) penyebab penyakit kuning keriting pada tanaman cabai merah var.horizon. Flavonoid dan saponin berfungsi sebagai zat anti mikrobia sedangkan alkaloid berfungsi sebagai zat anti serangga, dengan mekanisme perusakan sistem saraf dan sistem pernapasan serangga.

\section{SIMPULAN}

a. Pestisida nabati dari filtrat enceng gondok dan filtrat daun pepaya dapat digunakan untuk menekan intensitas serangan (\%) vektor virus kuning keriting, kutu kebul (Bemisia tabaci) yang menyerang tanaman cabai varietas Dewata F1

b. Penggunaan filtrat campuran berupa filtrat enceng gondok dan filtrat daun pepaya dengan perbandingan 1:1 fektif dalam mengurangi intensitas serangan kutu kebul (Bemisia tabaci) pada tanaman cabai merah varietas Dewata F1 sebesar 82,34\% namun produksi buahnya kurang memuaskan.

c. Penggunaan filtrat enceng gondok dapat menaikkan produksi buah cabai merah vareitas Dewata F1 dengan menekan intensitas serangan kutu kebul (Bemisia tabaci) sebesar $65,55 \%$.

\section{DAFTAR PUSTAKA}

Badan Pusat Statistik Indonesia (BPS). 2017. Statistik Indonesia 2017.

Ekawati, I dan Purwanto, Z., 2013. Alih Teknologi Pestisida Nabati Berbasis Sumberdaya Lokal Pada Petani Padi. Jurnal Cemara, Vol. 10(1): hal. 36-40. ISSN: 2087- 3484

Hidayat, A., 2009. Sumber Daya Lahan Indonesia: Potensi, Permasalahan, 


$\begin{array}{lr}\text { Dan } & \text { Strategi } \\ \text { Pemanfaatan. } & \text { Jurnal } \\ \text { Sumberdaya } & \text { Lahan } \\ \text { 3(2):107-117. } & \text { ISSN: } \\ \text { 1907-0799. } & \end{array}$

Kementerian Agraria Dan Tata Ruang Republik

Indonesia, 2016.

Peraturan Menteri

Agraria Dan Tata

Ruang/Kepala Badan

Pertanahan Nasional No.

19 Tahun 2016 Tentang

Penetapan Lahan

Pertanian Pangan

Berkelanjutan Pada

Wilayah Yang Belum

Terbentuk Rencana Tata

Ruang Wilayah

Kementerian Agraria Dan Tata

Ruang Republik

Indonesia, 2016.

Peraturan Menteri

Agraria Dan Tata

Ruang/Kepala Badan

Pertanahan Nasional No.

19 Tahun 2016 Tentang

Penetapan Lahan

Pertanian Pangan

Berkelanjutan Pada

Wilayah Yang Belum

Terbentuk Rencana Tata

Ruang Wilayah

Kementerian Pertanian Republik

Indonesia,

2011.

Peraturan Menteri

Pertanian No. 24 Tahun

2011 Tentang Syarat dan

Tatacara Pendaftaran

Pestisida.

Sayuti, M dan Hasanuddin., 2016.

Pemanfaatan Potensi

Danau Limboto Dengan

Mengoptimalisasikan

Peran Ibu Rumah Tangga

Untuk Meningkatkan

Kreatifitas Keuarga

Sejahtera (KKS) Dan

Pendapatan Masyarakat

Di Kecamatan Tilango,
Gorontalo. Prosiding

Seminar Nasional Lahan

Basah, hal. 426-430.

ISBN: 978-602-6483-331.

United Nation, 2012. The Future We Want. Resolution Adopted By The General Assembly A/Res/66/288

United Nation, 2014. Better Nutrition, Better Lives. 2ndInternational

Conference on Nutrition (ICN2). Food And Agriculture Organization, 19-21 November 2014, Rome, Italy

United Nation, Division for Sustainable Development, Department of Economic and Social Affairs. Sumber daring: https://sustainabledevelop ment.un.org/topics/fooda griculture

Wijaya, D., Yanti, P.P., Rafty, S.A., dan Rizal, M., 2015. Screening Fitokimia Dan Aktivitas Antioksidan Daun Eceng Gondok (Eichhornia Crassipes). Jurnal Kimia Valensi, Vol. 1(1): hal. 65-69. DOI:

http://dx.doi.org/10.1540 8/jkv.v0i0.4965

Wismaningsih, E.R dan Oktaviasari, D.I., 2016. Identifikasi Jenis Pestisida Dan Penggunaan APD Pada Petani Penyemprot Di Kecamatan Ngantru Kabupaten Tulungagung. Jurnal Wiyata, Vol. 3(1): hal. 100-105. ISSN: 2355-6498 